\title{
Integrating sludge drying in biomass fueled CHP plants
}

\author{
Jinshan Wang ${ }^{1,2} \cdot$ Chaudhary Awais Salman ${ }^{1} \cdot$ Bin Wang $^{2} \cdot$ Hailong Li $^{1}$ (D) \\ Eva Thorin ${ }^{1}$ \\ ${ }^{1}$ School of Business, Society and Engineering, Mälardalen University, 72123 Västerås, Sweden \\ ${ }^{2}$ Key Laboratory of Refrigeration Technology of Tianjin, Tianjin University of Commerce, Tianjin 300134, China
}

Received: 26 June 2020/Revised: 23 August 2020/Accepted: 29 August 2020/Published online: 14 September 2020

(C) The Author(s) 2020

\begin{tabular}{|c|c|c|}
\hline Abstract Handling sludge through thermal conversion is & $C_{\mathrm{d}}$ & Drag force coefficient \\
\hline environmentally friendly, which, however, requires sludge & $c_{\mathrm{FG}}$ & Specific heat of FG $(\mathrm{J} / \mathrm{kg} \mathrm{K})$ \\
\hline drying. This work proposed to use the waste heat of flue & $c_{\mathrm{PG}}$ & Specific heat of air (J/kg K) \\
\hline gas (FG) to dry sludge. The integration of sludge drying in & $c_{\mathrm{pv}}$ & Specific heat of water vapor $(\mathrm{J} / \mathrm{kg} \mathrm{K})$ \\
\hline biomass fueled combined heat and power (CHP) plants can & $c_{\mathrm{pw}}$ & Specific heat of liquid water $(\mathrm{J} / \mathrm{kg} \mathrm{K})$ \\
\hline clearly affect the performance of downstream processes in & $d$ & Diameter of droplets $(\mathrm{m})$ \\
\hline $\begin{array}{l}\text { FG cleaning, such as flue gas quench (FGQ) and flue gas } \\
\text { condenser, and further affect the energy efficiency of CHP. }\end{array}$ & $\mathrm{d} U_{\text {sludge }}$ & $\begin{array}{l}\text { Heat used to change the temperature of sludge } \\
\text { bed }(\mathrm{J})\end{array}$ \\
\hline In order to understand the influence, a mathematical model & $G$ & Flow rate of dry $\mathrm{FG}(\mathrm{kg} / \mathrm{s})$ \\
\hline and an Aspen PLUS model were developed to simulate the & $g$ & Acceleration of gravity $\left(\mathrm{m} / \mathrm{s}^{2}\right)$ \\
\hline $\begin{array}{l}\text { drying process and the CHP, respectively. Based on sim- } \\
\text { ulations, it is found that the increase of feeding rate of }\end{array}$ & $\Delta H$ & $\begin{array}{l}\text { Latent heat of vaporization in the surface water } \\
\text { of sludge }(\mathrm{J} / \mathrm{kg})\end{array}$ \\
\hline sludge and the moisture content of sludge after drying can & $h$ & Coefficient of heat transfer in FGQ $\left(\mathrm{W} / \mathrm{m}^{2} \mathrm{~K}\right)$ \\
\hline $\begin{array}{l}\text { decrease the water evaporation in FGQ. An increase in the } \\
\text { feeding rate of sludge in combination with a drop of }\end{array}$ & $h_{\mathrm{bw}}$ & $\begin{array}{l}\text { Heat transfer coefficient of static sludge }(\mathrm{W} / \\
\left.\mathrm{m}^{2} \mathrm{~K}\right)\end{array}$ \\
\hline $\begin{array}{l}\text { moisture content of sludge after drying can decrease the } \\
\text { heat recovery from FG. When using dried sludge to replace }\end{array}$ & $h_{\mathrm{c}}$ & $\begin{array}{l}\text { Coefficient of convective heat transfer in the } \\
\text { surface of sludge }\left(W / \mathrm{m}^{2} \mathrm{~K}\right)\end{array}$ \\
\hline biomass, the amount of saving could be influenced by the & $h_{\mathrm{m}}$ & Coefficient of mass transfer in FGQ $\left(\mathrm{W} / \mathrm{m}^{2} \mathrm{~K}\right)$ \\
\hline $\begin{array}{l}\text { moisture content after drying and the flow rate of sludge. } \\
\text { Simulation results show that drying sludge to a moisture }\end{array}$ & $h_{\mathrm{rad}}$ & $\begin{array}{l}\text { Coefficient of radiant heat transfer in the surface } \\
\text { of sludge }\left(W / \mathrm{m}^{2} \mathrm{~K}\right)\end{array}$ \\
\hline content of $40 \%$ leads to the maximum biomass saving. & $h_{\mathrm{ws}}$ & $\begin{array}{l}\text { Complex coefficient of heat transfer between } \\
\text { FG and sludge }\left(\mathrm{W} / \mathrm{m}^{2} \mathrm{~K}\right)\end{array}$ \\
\hline Keywords Flue gas quench $\cdot$ Heat recovery $\cdot$ Sludge & $M_{\mathrm{H}_{2} \mathrm{O}}$ & Mole mass of water $(\mathrm{g} / \mathrm{mol})$ \\
\hline drying $\cdot$ CHP $\cdot$ Energy efficiency & $M_{\text {air }}$ & Mole mass of air $(\mathrm{g} / \mathrm{mol})$ \\
\hline & $m_{\mathrm{DS}}$ & Mass of dry sludge (kg) \\
\hline List of symbols & $m_{\mathrm{d}}$ & Mass of water droplets $(\mathrm{kg})$ \\
\hline $\begin{array}{l}A_{1} \quad \text { Contact area between the sludge and the heated } \\
\text { wall }\left(\mathrm{m}^{2}\right)\end{array}$ & $\begin{array}{l}m_{\mathrm{FG}} \\
m_{\mathrm{v}}\end{array}$ & $\begin{array}{l}\text { Mass flow rate of FG }(\mathrm{kg} / \mathrm{s}) \\
\text { Drying rate }\left(\mathrm{kg} / \mathrm{m}^{2} \mathrm{~s}\right)\end{array}$ \\
\hline Heat dissipation area of sludge $\left(\mathrm{m}^{2}\right)$ & $P_{\mathrm{T}}$ & Total pressure $(\mathrm{Pa})$ \\
\hline Area of heat and mass transfer per unit time in & $P_{\mathrm{V}}$ & Partial vapor pressure of sweeping air $(\mathrm{Pa})$ \\
\hline FGQ $\left(\mathrm{m}^{2} / \mathrm{s}\right)$ & $P_{\mathrm{V}, \mathrm{S}}\left(T_{\mathrm{s}}\right)$ & $\begin{array}{l}\text { Partial vapor pressure of the surface of sludge } \\
(\mathrm{Pa})\end{array}$ \\
\hline $\begin{array}{l}\text { Hailong Li } \\
\text { hailong.li@ }\end{array}$ & $\begin{array}{l}Q_{\mathrm{cv}} \\
Q_{\mathrm{in}}\end{array}$ & $\begin{array}{l}\text { Released heat of FG in a control unit }(\mathrm{J}) \\
\text { Heat of FG enters the sludge bed }(\mathrm{J})\end{array}$ \\
\hline
\end{tabular}




$\begin{array}{ll}Q_{\text {sen }} & \text { Sensible heat transferred into sweeping air }(\mathrm{J}) \\ Q_{\text {evap }} & \text { Latent heat transferred into sweeping air }(\mathrm{J}) \\ Q_{\text {out }} & \begin{array}{l}\text { Rest heat transferred into the sweeping air from } \\ \text { sludge bed }(\mathrm{J})\end{array} \\ T_{\text {bed }, i} & \begin{array}{l}\text { Initial temperature of sludge in the one contact } \\ \text { period }\left({ }^{\circ} \mathrm{C}\right)\end{array} \\ & \text { FG temperature in dryer }\left({ }^{\circ} \mathrm{C}\right) \\ T_{\mathrm{FG}} & \text { Sweeping air temperature }\left({ }^{\circ} \mathrm{C}\right) \\ T_{\mathrm{G}} & \text { Surface temperature of sludge }\left({ }^{\circ} \mathrm{C}\right) \\ T_{\mathrm{s}} & \text { Water droplet temperature }\left({ }^{\circ} \mathrm{C}\right) \\ T_{\mathrm{w}} & \text { Velocity of droplet }(\mathrm{m} / \mathrm{s}) \\ u_{\mathrm{d}} & \text { Velocity of the FG before } \mathrm{FGQ}(\mathrm{m} / \mathrm{s}) \\ u_{\mathrm{g}} & \text { Moisture content of sludge }(\mathrm{kg} / \mathrm{kg}) \\ X & \text { Saturated humidity at droplet surface }(\mathrm{kg} / \mathrm{kg}) \\ y_{\mathrm{s}} & \end{array}$

\section{Symbols}

$\lambda$ Heat conductivity coefficient of FG (W/m K)

$\lambda_{q} \quad$ Heat of vaporization in FGQ $(\mathrm{J} / \mathrm{kg})$

$\rho_{\mathrm{g}}$ FG density $\left(\mathrm{kg} / \mathrm{m}^{3}\right)$

\section{Introduction}

With the unceasing growth of wastewater, the amount of sludge increases rapidly (Kor-Bicakci et al. 2019; Zheng et al. 2020), which has become one of the most severe environmental problems around the world. The conventional methods of sludge management are through landfilling or agricultural applications. However, the contents of heavy metals, organic pollutants and pharmaceuticals result in a high risk of secondary pollution and therefore, they might no longer be viable due to more strict regulations and the rising environmental and health concerns (Kim et al. 2019; Wang et al. 2019a). For example, the requirements of European directives 99/31/EU already indicate that landfilling of sludge is not a desirable option (The council of the European Union 1999).

Instead of being buried directly, sludge can be handled through thermal conversion, such as: pyrolysis, gasification and incineration. Pyrolysis is regarded as environmentally friendly technology, in which sludge could be converted to bio-oil and bio-char. However, drying is usually needed due to the high moisture content (Kuan et al. 2020). Gasification occurs at a higher temperature. The advantages of sludge gasification include complete sterilization of sludge and large mass reduction (Lee et al. 2013). Nevertheless, drying is also demanded to a moisture content lower than 25\% (Ayol et al. 2019). Sludge incineration is attracting more interest (Murakami et al. 2009), which can significantly reduce sludge volume, eliminate odor and stabilize sludge (Chen et al. 2017). Similar to pyrolysis and gasification, wet sludge cannot be incinerated directly. Moreover, the high moisture content can also affect the other performances of sludge incineration, including pollutant emission through both flue gas (FG) and wastewater, combustion efficiency and energy recovery.

Many works have been done about sludge drying (Ameri et al. 2020). Usually, dryers can be divided into direct drying, indirect drying and hybrid drying (or mixed drying). For direct drying, heat medium passes through sludge and water is vaporized. Examples include direct heating drum dryer (Farid et al. 2019), flash dryer and belt dryer (Tańczuk et al. 2016). Hot-air (heating by the electrical heater), steam and FG are commonly used as the heat medium. Direct drying has the advantages of easy manipulation, but it has the relatively long drying time, bad odors and gaseous emissions (Léonard et al. 2008; Arlabosse et al. 2011; Fraikin et al. 2011). The specific energy consumption is ranged from 700 to $1400 \mathrm{~kW} \mathrm{h/t}$, and the specific drying rate varies from 0.2 to $30 \mathrm{~kg} / \mathrm{m}^{2} \mathrm{~h}$ (Bennamoun et al. 2013). For indirect drying, the sludge is heated through a heat exchanger, for instance the rotary dryer, vertical multi-tray dryer and paddle dryer (Schnell et al. 2020; Charlou et al. 2015). Indirect drying can avoid the pollution of the heat carrying medium and reduce the risks of fire and explosion. The volatile organic compounds (VOC) concentration is low, and the steam and odor is confined (Ferrasse et al. 2002). But during indirect drying, the sludge exepriences a period of sticky phase, which can alter dryer performance (Kudra 2003; Deng et al. 2009). The specific energy consumption is ranged from 800 to $955 \mathrm{~kW} \mathrm{h/t}$, and the specific drying rate varies from 7 to $35 \mathrm{~kg} / \mathrm{m}^{2} \mathrm{~h}$. The dried product by the indirect drying usually is used in industrial applications (Bennamoun et al. 2013). Hybrid drying combines different technologies, for example the fluidized bed drying combines the convection and conduction.

Considering the large water content of sludge, the energy demand for drying is substantially high. Fortunately, drying does not need high temperature heat, therefore, a lot of efforts have been dedicated to the integration of sludge drying in order to use available waste heat (Chin et al. 2008; Akdağ et al. 2018; Xu et al. 2018). Bianchini et al. (2015) proposed to use the FG between the economizer and the FG quench (FGQ). Based on a waste-toenergy power plant in Bologna, Italy, sludge dried by $1 \mathrm{MW}$ heat taken from FG can produce 1.5 MW heat after incineration. However, this work mainly focused on the feasibility of integrating sludge drying in the power plant. The details of drying was not considered, which can result in a high uncertainty. Dai et al. (2018) also studied using FG for sludge drying. Results show that the sludge drying capacity can reach 86 ton/day with the FG temperature $160{ }^{\circ} \mathrm{C}$; however, the location of $\mathrm{FG}$ extraction was not specified. Ma et al. (2012) developed a two-stage drying using FG after air preheater from a coal-fired thermal 
power plant, which can extend sludge contact time with FG. Experiment results show that the new technique is very effective, which can save the heating cost in sludge drying by $80 \%$. But it still remains unclear how the integration of sludge drying using FG can affect the downstream processes and the performance of CHP.

In addition, biomass and waste with high moisture content have been widely utilized in power generation. Nevertheless, the EU Water Framework Directive requires reducing withdrawing freshwater externally, increase water recycles and reuse internally for reducing the disturbance to natural water. Our previous study has justified that adding a flue gas quench before flue gas condenser (FGC), as shown in Fig. 1, is an effective way to reduce the cost of wastewater treatment and remove water-soluble pollutants (Emad and Nils 2017; Wang et al. 2019b). The temperature of FG is up to $163{ }^{\circ} \mathrm{C}$ before the flue gas quench ( $\mathrm{Li}$ et al. 2019), which implies that some waste heat is still available in FG and can be used, for example, for sludge drying. After drying, sludge could be sent to boiler as the fuels. The benefits are multiple: It not only reduces the external energy demand for sludge drying, but also converts sludge to fuel, which can replace some feedstock.

The integration of sludge drying can clearly affect the performance of the downstream process FGQ. Since FG has a lower temperature after sludge drying, less heat will be brought into FGQ, resulting in less water evaporation. The change of water evaporation can change the pollutant concentration, which can further affect the amount of water rejected to the boiler and consequently, the energy efficiency. In addition, the change of water evaporation can also affect the water demand from the external water sources. However, such impacts have not been studied quantitatively. Therefore, the objective of this work is to assess the impacts of integrating sludge drying on the performance of FGQ and the entire biomass-fired CHP plant. A numerical model was implemented in MATLAB for the simulation of a sludge drying, which was also integrated into a system model of a CHP plant. This study provides insights about the sludge drying integration, which consider not only the waste heat recovery from FG but also the performance of wastewater treatment.

\section{Model description}

\subsection{Model of sludge drying}

\subsubsection{Related works about modeling dryer}

Numerous models have been developed to study the heat and mass transfer in sludge drying, such as the penetration model, discrete element model, pore network model and population equilibrium model (Ferrasse et al. 2002; Mahmoud et al. 2010). The advantage of the penetration model comes from its ability to simulate the kinetics of lumpy, pasty and granular phases of sludge during drying (Arlabosse and Chitu 2007). Tsotsas and Schlünder (1986) firstly adopted the penetration model to simulate the drying of sludge. The dry matter was assumed to be fixed during both pasty and granular regimes, and the mass transfer resistance was not considered in the gas phase because the vapor was used as sweeping gas during the contact drying experiment. The results showed that the relative deviations on moisture content and temperature were less than $13 \%$ and $7.5 \%$, respectively. Deng et al. (2013) applied the

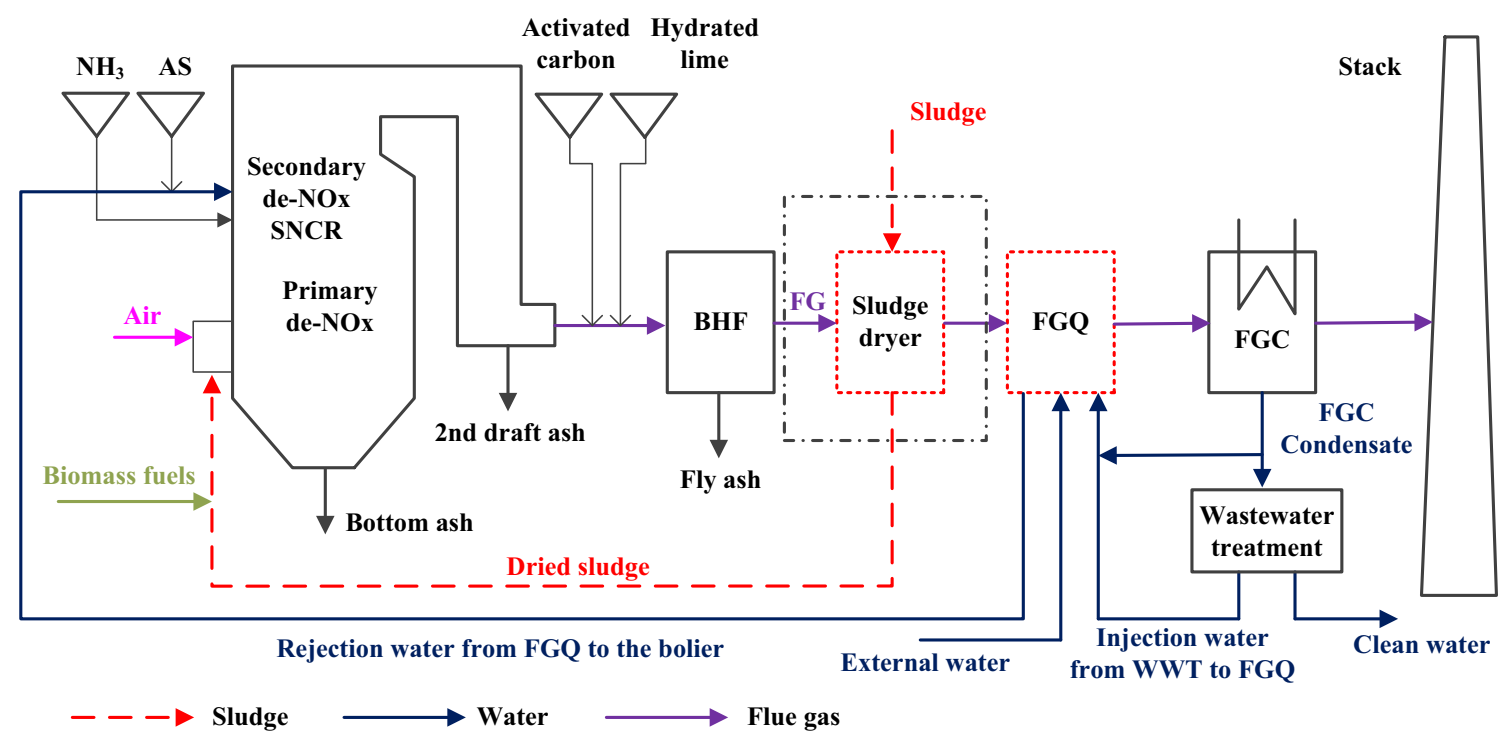

Fig. 1 Schematic of biomass CHP plant for emission control and waste heat utilization of FG process (Galanopoulos 2015; Li et al. 2019) 
penetration model on a paddle dryer using oil as heat carrier or with a hot shaft. Different sludge states, e.g. sticky, lumpy and particulate, and the mass transfer resistances in the gas phase were considered. A good agreement with the experimental data was reported for different drying rates and sludge temperatures. Because the penetration model assumes that the drying can be described by a series of static periods, during which transient heat transfer and water evaporation occur separated by instantaneous macromixing of the bulk, it is difficult to combine it with a continuous flow model (Mahmoud et al. 2010). To overcome this, Milhé et al. (2016) proposed that the Markov chains-based flow model can be integrated into the penetration model when both models have the same time-scale during simulations. This method was used to study the sludge flow and heat transfer in a continuous dryer to further understand the drying mechanism. Good consistency was observed between the calculation and experimental results (Milhé et al. 2015; Chen et al. 2016). Therefore, the penetration model and the Markov chainsbased flow model were adopted in this work.

\subsubsection{Mathematical model of sludge drying}

Considering the transition of sludge state during dehydration (from initial pasty state to sticky state), the paddle dryer has been widely developed and applied. It consists of a $U$-shaped tough with the rotating shaft inside, and the paddles are regularly spaced on the shaft. The wedgeshaped paddles with high shearing stress can avoid sludge clogging in the dryer. Moreover, it has high heat fluxes, low specific energy consumptions and low exhaust volumes (Milhé et al. 2015).

In this study, the paddle dryer consists of wedge blades, two hollow shafts and a jacket. The heat was transferred from FG to the shafts and wedge blades when the FG goes through the hollow shafts. With the increase of sludge temperature, the sweeping air at the top of sludge bed carries out the evaporated water from sludge. The drying characters are studied when the FG is used as heat carrier based on the percolation model, which is applied to get the spatial distribution characteristic combined with the Markov chains-based flow model. As shown in Fig. 2, the heat released from $\mathrm{FG}\left(Q_{\text {in }}\right)$ is used to heat sludge $\left(\mathrm{d} U_{\text {sludge }}\right)$ and vaporize water $\left(Q_{\text {out }}\right)$, which can be further broken down to latent heat $\left(Q_{\text {evap }}\right)$ and sensible heat $\left(Q_{\text {sen }}\right)$.

According to the energy conservation and Newton's law of cooling, the equations of energy balance of sludge and heat transfer are as follows:

$Q_{\text {in }}=\mathrm{d} U_{\text {sludge }}+Q_{\text {out }}$

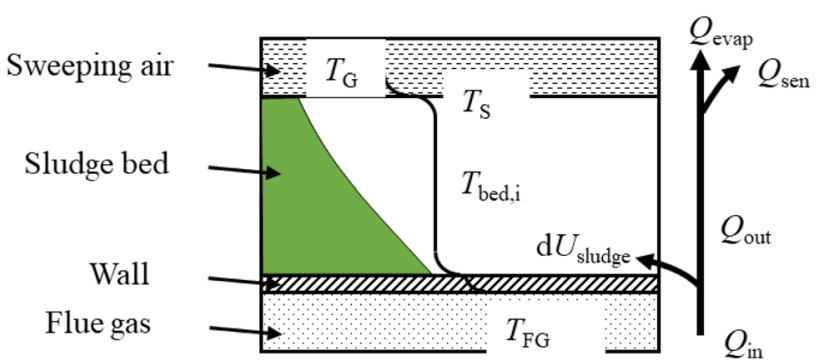

Fig. 2 Temperature profiles and heat transfer during drying (Chen et al. 2017)

$Q_{\mathrm{in}}=h_{\mathrm{ws}} A_{1}\left(T_{\mathrm{FG}}-T_{\text {bed }, i}\right)$

$Q_{\text {out }}=Q_{\text {evap }}+Q_{\text {sen }}$

where $h_{\mathrm{ws}}$ is the total coefficient of heat transfer between the FG and sludge $\left(\mathrm{W} / \mathrm{m}^{2} \mathrm{~K}\right) ; A_{1}$ represents the contact area between the sludge and the heated wall $\left(\mathrm{m}^{2}\right) ; T_{\mathrm{FG}}$ is the FG temperature; and $T_{\mathrm{bed}, i}$ is the initial temperature in the one contact period $\left({ }^{\circ} \mathrm{C}\right)$.

Sludge also exchanges heat with the sweeping air, which can be expressed by Eq. (4) as follows:

$Q_{\text {out }}=h_{\text {bw }} A_{2}\left(T_{\text {bed }, i}-T_{\mathrm{s}}\right)$.

The $Q_{\text {out }}$ includes two parts: $Q_{\text {sen }}$ and $Q_{\text {evap }}$. The sensible heat $Q_{\text {sen }}$ is calculated as:

$Q_{\text {sen }}=A_{2}\left(h_{\mathrm{c}}+h_{\mathrm{rad}}\right)\left(T_{\mathrm{s}}-T_{\mathrm{G}}\right)$.

The amount of latent heat $Q_{\text {evap }}$ is calculated as:

$Q_{\text {evap }}=m_{\mathrm{v}} \Delta H$

where $h_{\mathrm{bw}}$ is the heat transfer coefficient of sludge (W/ $\left.\mathrm{m}^{2} \mathrm{~K}\right) ; A_{2}$ represents the heat dissipation area of sludge $\left(\mathrm{m}^{2}\right) ; T_{\mathrm{s}}$ is the surface temperature of sludge $\left({ }^{\circ} \mathrm{C}\right), h_{\mathrm{c}}$ and $h_{\text {rad }}$ are the coefficients of convective heat transfer and coefficient of radiant heat transfer, respectively, between sludge and sweeping air $\left(\mathrm{W} / \mathrm{m}^{2} \mathrm{~K}\right) ; T_{\mathrm{G}}$ is the sweeping air temperature $\left({ }^{\circ} \mathrm{C}\right) ; m_{\mathrm{v}}$ represents the drying rate $\left(\mathrm{kg} / \mathrm{m}^{2} \mathrm{~s}\right)$; and $\Delta H$ is the latent heat of vaporization in the surface water of sludge $(\mathrm{J} / \mathrm{kg})$.

The heat transfer resistance in the paddle dryer includes convective resistance between the FG and wall of the dryer $\left(1 / h_{\mathrm{FG}}\right)$, conductive resistance of dryer shell $\left(1 / h_{\mathrm{wall}}\right)$ and contact resistance between the sludge and wall of dryer (1/ $h_{\text {cont }}$ ). Then, $h_{\mathrm{ws}}$ is calculated by Eq. (7):

$\frac{1}{h_{\mathrm{ws}}}=\frac{1}{h_{\mathrm{fg}}}+\frac{1}{h_{\mathrm{wall}}}+\frac{1}{h_{\text {cont }}}$

$h_{\mathrm{FG}}$ can be calculated by the correlation of Dittus-Boelter (Deng et al. 2013): 
$h_{\mathrm{FG}}=0.023 \frac{\lambda}{d} \operatorname{Re}^{0.8} \operatorname{Pr}^{0.3}$

where $\lambda$ is the heat conductivity coefficient of FG (W/ $\mathrm{m} \mathrm{K}$ ); and $d$ is the inner diameter of shaft (m). The drying rate can be expressed as (Salman et al. 2017):

$m_{\mathrm{v}}=\frac{A_{2}}{A_{1}} \frac{h_{\mathrm{c}}}{c_{\mathrm{PG}}} \frac{M_{\mathrm{H}_{2} \mathrm{O}}}{M_{\mathrm{air}}} \ln \frac{P_{\mathrm{T}}-P_{\mathrm{V}}}{P_{\mathrm{T}}-P_{\mathrm{V}, \mathrm{S}}\left(T_{\mathrm{s}}\right)}$

$c_{\mathrm{PG}}$ expresses the specific heat of air $(\mathrm{J} / \mathrm{kg} \mathrm{K}) ; P_{\mathrm{T}}$ represents the total pressure $(\mathrm{Pa}) ; P_{\mathrm{V}}$ and $P_{\mathrm{V}, \mathrm{S}}\left(T_{\mathrm{s}}\right)$ are the partial vapor pressure of the sweeping air and the surface of sludge, respectively (Pa); and $M_{\mathrm{H}_{2} \mathrm{O}}$ and $M_{\text {air }}$ are the mole mass of water and air, respectively $(\mathrm{g} / \mathrm{mol})$.

In each contact time period, the variation of moisture content of sludge can be calculated by Eq. (10)

$X_{i+1}=X_{i}-\frac{m_{\mathrm{v}} t_{\mathrm{R}} A_{1}}{m_{\mathrm{DS}}}$

where $X$ expresses the moisture content of sludge $(\mathrm{kg} / \mathrm{kg})$; and $m_{\mathrm{DS}}$ is the mass of dry sludge $(\mathrm{kg})$.

According to the equations from (1) to (10), the dynamic results of sludge can be obtained. To get the spatial distribution characteristics of sludge in the dryer, the one-dimensional Markov chain model (Milhé et al. 2015; Chen et al. 2016) is introduced into the percolation mode. The drying process is divided into several control units in the forward direction of sludge. The length of each control unit is limited by the distance of sludge flow within a contact period. The sludge state can be calculated based on the flow rate of sludge and the penetration model, along with the drying process. The temperature of FG can be calculated in each unit by Eq. (11)

$\left.T_{\mathrm{FG}}\right|_{z}-\left.T_{\mathrm{FG}}\right|_{z+\Delta \mathrm{Z}}=\frac{Q_{\mathrm{cv}}}{m_{\mathrm{FG}} c_{\mathrm{FG}}}$

where $m_{\mathrm{FG}}$ is the mass flow rate of $\mathrm{FG}(\mathrm{kg} / \mathrm{s}) ; c_{\mathrm{FG}}$ represents the specific heat of $\mathrm{FG}(\mathrm{J} / \mathrm{kg} \mathrm{K})$; and $Q_{\mathrm{cv}}$ is the released heat of FG in a control unit $(\mathrm{J})$. The above equations could be solved by Matlab.

\subsection{FGQ model}

After drying the sludge, FG enters the FG quench (FGQ). FG enters the column from the bottom and passes through the quench, while recycling water is sprayed in the top and gets in contact with FG when dropping down, as shown in Fig. 3. A simplified one-dimension mathematic model was built based on the energy and water balance. The quench column can divided into a number of segments. For each segment, the government equations of the velocity (Eq. 12), mass transfer (Eq. 13) and heat transfer (Eq. 14)

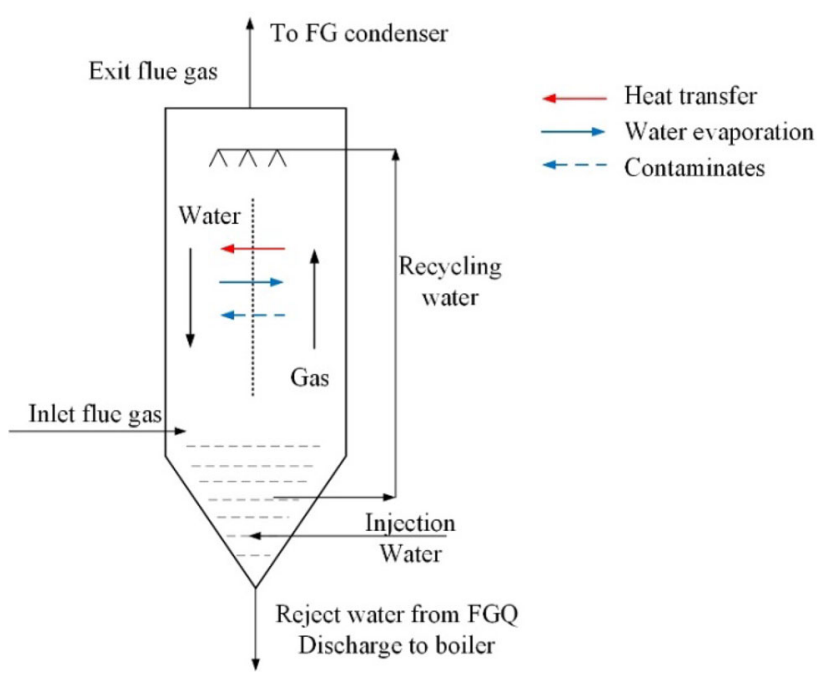

Fig. 3 Schematic diagram of flue gas quench

were setup. More details can be found in our previous work (Li et al. 2019).

$\frac{\partial\left(m_{\mathrm{d}} u_{\mathrm{d}}\right)}{\partial t}=m_{\mathrm{d}} g-\rho_{\mathrm{g}} \frac{\pi}{6} d^{3} g-\frac{C_{\mathrm{d}} \rho_{\mathrm{g}}}{2} \frac{\pi d^{2}}{4}\left(u_{\mathrm{d}}+u_{\mathrm{g}}\right)^{2}$

where $m_{\mathrm{d}}$ is the water droplet mass $(\mathrm{kg}) ; u_{\mathrm{d}}$ is velocity of droplet $(\mathrm{m} / \mathrm{s}) ; g$ represents the acceleration of gravity $(\mathrm{m} /$ $\left.\mathrm{s}^{2}\right) ; \rho_{\mathrm{g}}$ represents FG density $\left(\mathrm{kg} / \mathrm{m}^{3}\right) ; d$ is the diameter of droplet $(\mathrm{m}) ; u_{\mathrm{g}}$ represents the velocity of the FG before FGQ $(\mathrm{m} / \mathrm{s})$; and $C_{\mathrm{d}}$ represents the drag force coefficient, it is determined by droplet Reynolds number.

$G\left(\left.y\right|_{z+\Delta z}-\left.y\right|_{z}\right)=h_{\mathrm{m}} \rho_{\mathrm{g}}\left(y-y_{\mathrm{s}}\right) A_{\mathrm{w}} \Delta t$

where $G$ represents the flow rate of dry FG $(\mathrm{kg} / \mathrm{s}) ; h_{\mathrm{m}}$ is the coefficient of mass transfer $\left(\mathrm{W} / \mathrm{m}^{2} \mathrm{~K}\right) ; y_{\mathrm{s}}$ represents the saturated humidity at droplet surface $(\mathrm{kg} / \mathrm{kg})$; and $A_{\mathrm{w}}$ represents the area of heat and mass transfer per unit time $\left(\mathrm{m}^{2} /\right.$ s).

$\frac{\partial T_{\mathrm{w}}}{\partial Z}=\frac{6 h\left(T_{\mathrm{FG}}-T_{\mathrm{w}}\right)+6 h_{\mathrm{m}} \rho_{\mathrm{g}}\left(y-y_{\mathrm{s}}\right) \lambda_{q}}{c_{\mathrm{pw}} \mathrm{d} \rho_{\mathrm{w}} u_{\mathrm{d}}}-\frac{3 T_{\mathrm{w}}}{d} \frac{\mathrm{d} d}{\mathrm{~d} Z}$

$\frac{\partial T_{\mathrm{FG}}}{\partial Z}=\frac{h A_{\mathrm{w}}\left(T_{\mathrm{FG}}-T_{\mathrm{w}}\right)}{\left(c_{\mathrm{FG}}+y c_{\mathrm{pv}}\right) G u_{\mathrm{d}}}$

where $h$ the is coefficient of heat transfer $\left(\mathrm{W} / \mathrm{m}^{2} \mathrm{~K}\right) ; T_{\mathrm{w}}$ is the water droplet temperature $\left({ }^{\circ} \mathrm{C}\right) ; \lambda_{q}$ represents heat of vaporization $(\mathrm{J} / \mathrm{kg})$; and $C_{\mathrm{pw}}$ and $C_{\mathrm{pv}}$, respectively, represent specific heat of liquid water and water vapor $(\mathrm{J} / \mathrm{kg} \mathrm{K})$.

\subsection{CHP model}

A CHP plant model is developed in Aspen Plus, as shown in Fig. 4, which can be divided into three sections: The boiler section for the combustion of biomass and steam generation, the steam turbine section for power and district 
heat production and FG section including sludge drying, FGQ and FGC. For sludge drying, the heat is taken from the FG between the economizer and FGQ. In addition, the sludge drying model, which can provide the amount of heat needed by sludge drying, and the FGQ model, which can provide the amount of recirculated heat in FGQ and the variation of FG temperature and moisture content after FGQ, are also implemented.

To simplify the simulation, it is assumed in that the combustion temperature (i.e., the temperature of FG leaving the boiler) is fixed and the amount of steam produced in the boiler is constant. The operation parameters of the CHP could be found in $\mathrm{Li}$ et al. (2019). Table 1 shows the proximate and ultimate analysis (dry ash-free basis) of the biomass and sludge (Salman et al. 2017, 2019; Stockholm Water and Waste 2019), used in this study.

\subsection{Model validation}

The models of FGQ and the CHP plant without sludge drying have been validated in our previous work ( $\mathrm{Li}$ et al. 2019). To validate the sludge drying model, the simulated results are compared with the experimental results from (Deng et al. 2009). Oil is used as heat carrier, and some key parameters of the experiment are listed in Table 2 (Deng et al. 2009).

The variations of temperature of sludge and drying rate with the moisture content of sludge are shown in Fig. 5. In general, a good agreement can be observed when the moisture content is higher than $30 \%$. The reason that the calculated sludge temperature is lower than the measured result is due to the granular form of the sludge with a certain size, which reduces the role of paddles in breaking up sludge. The granular form sludge with the dry mud surface which prevents further drying of sludge, and the drying rate decreases significantly. It results in a fast increase of sludge temperature in experiments. But in model, it is hard to consider such a change in sludge state, which further changes the parameters of sludge drying. Since sludge will only be dried to a moisture content over $30 \%$ in this work, this model is considered as valid.

\section{Performance of sludge drying}

The performance of sludge drying is affected by many operating parameters, such as the flow rate of sludge and the velocity of FG. The reference flow rate of sludge is estimated based on the annual sludge amount from a real WWTP in Sweden, which gives $980 \mathrm{~kg} / \mathrm{h}$. Before the dryer, the temperature of $\mathrm{FG}$ is $163^{\circ} \mathrm{C}$, and the flow rate of FG is $93.68 \mathrm{~kg} / \mathrm{s}$, which are obtained from a real CHP plant (Li et al. 2019).

\subsection{Influence of the flow rate of sludge}

Figure 6 presents the influence of the feeding rate of sludge on the moisture content of exit sludge and the temperature of exit FG from the dryer. With the increase in feeding rate of sludge, the moisture content of exit sludge increases while the temperature of exit FG decreases. The increase in moisture content is due to a short staying time of sludge in

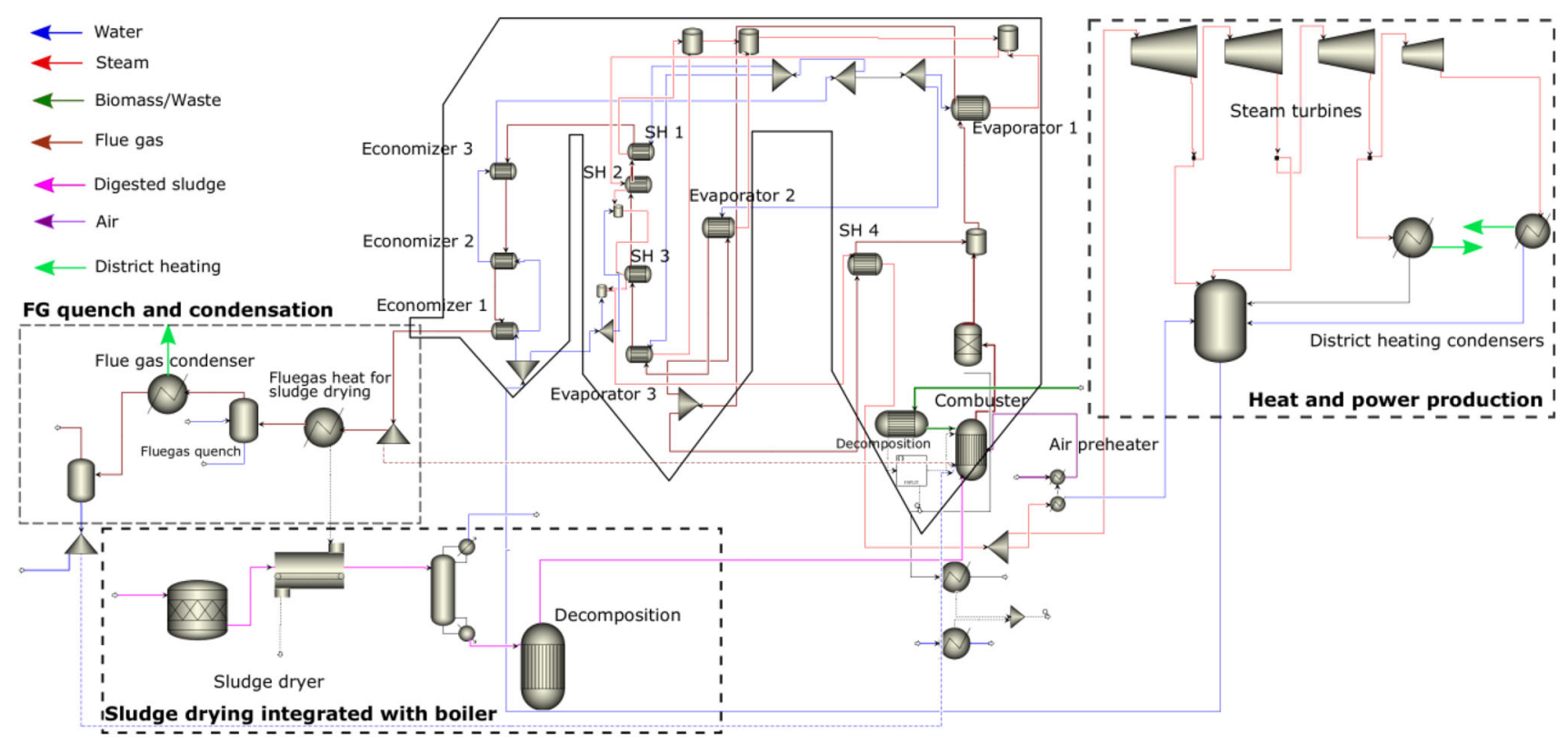

Fig. 4 Aspen plus model of CHP with sludge drying and co-incineration 
Table 1 The proximate and ultimate analysis (dry ash-free basis) of the biomass and sludge

\begin{tabular}{llrlll}
\hline Ultimate analysis (wt\%) & Biomass & Sludge & Proximate analysis (wt \%) & Biomass & Sludge \\
\hline Ash & 15 & 40.4 & Moisture & 40 & 80 \\
Carbon & 52.9 & 32.7 & Volatile & 35 & 49 \\
Hydrogen & 7.3 & 4.1 & Fixed carbon & 45 & 11 \\
Oxygen & 21.6 & 17.3 & LHV (MJ/kg) & 12 & 10 \\
Nitrogen & 1.6 & 4.3 & & & \\
Sulfur & 1.1 & 1.2 & & & \\
Chlorine & 0.5 & 0.1 & & & \\
\hline
\end{tabular}

Table 2 Parameters of sludge and sweeping air from experiments with oil as heat carrier, used for validation of the model

\begin{tabular}{llll}
\hline Sludge & & Sweeping air \\
\hline Mass $(\mathrm{kg})$ & 2.2 & Flow rate $\left(\mathrm{m}^{3} / \mathrm{h}\right)$ & 1.3 \\
Initial moisture content $(\%)$ & 80 & Relative humidity $(\%)$ & 60 \\
Initial temperature $\left({ }^{\circ} \mathrm{C}\right)$ & 30 & Temperature $\left({ }^{\circ} \mathrm{C}\right)$ & 20 \\
\hline
\end{tabular}

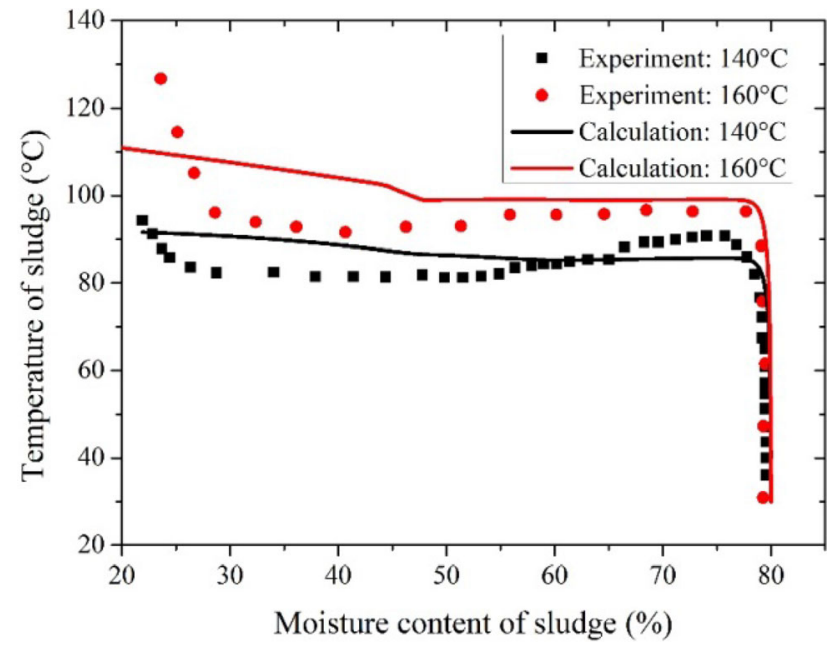

Fig. 5 Comparison between simulation results and experiments on sludge temperature

dryer, which reduces the mass transfer from sludge to sweeping air and therefore, leads to a higher moisture content. When it is assumed that after drying, the moisture content of exit sludge is $40 \%$, which is same as the moisture content of biomass, the maximum amount of sludge that can be handled by the FG is $8223 \mathrm{~kg} / \mathrm{h}$. Correspondingly, the temperature of exit FG drops to $129.8{ }^{\circ} \mathrm{C}$.

\subsection{Influence of the velocity of FG}

The sludge drying process can also be influenced by the velocity of FG. Figure 7 shows the results when the velocity of $F G$ increases from 10 to $15 \mathrm{~m} / \mathrm{s}$, while the stirrer speed and the feeding rate of sludge remain at

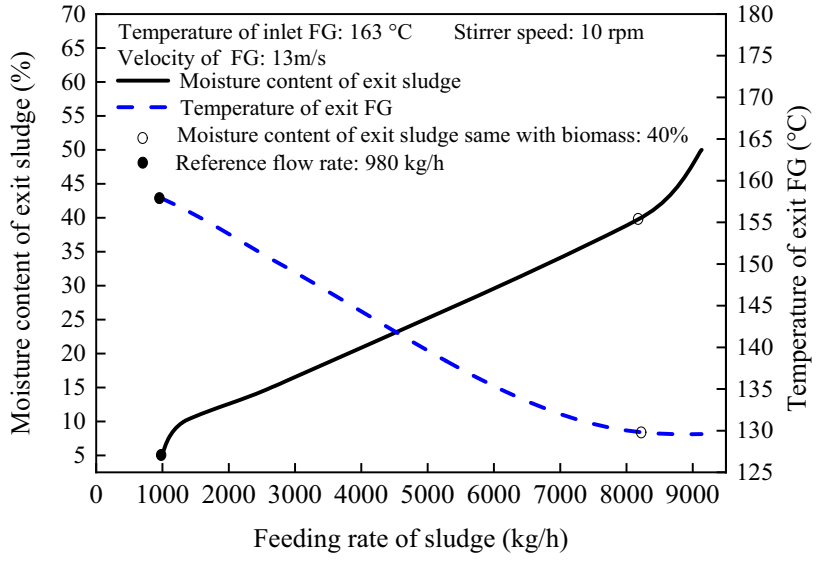

Fig. 6 Variation of moisture content of exit sludge and temperature of exit FG with the feeding rate of sludge

$10 \mathrm{rpm}$ and $980 \mathrm{~kg} / \mathrm{h}$, respectively. With the increase in FG velocity, both the moisture content of exit sludge and the temperature of exit FG decrease. This is due to the increase in heat transfer coefficient between FG and wall, which subsequently increase the heat transferred from FG to sludge. The drying rate of sludge increases with the increase of temperature of sludge. But the temperature of exit FG decreases from 151.6 to $149.2{ }^{\circ} \mathrm{C}$ with increase in FG velocity.

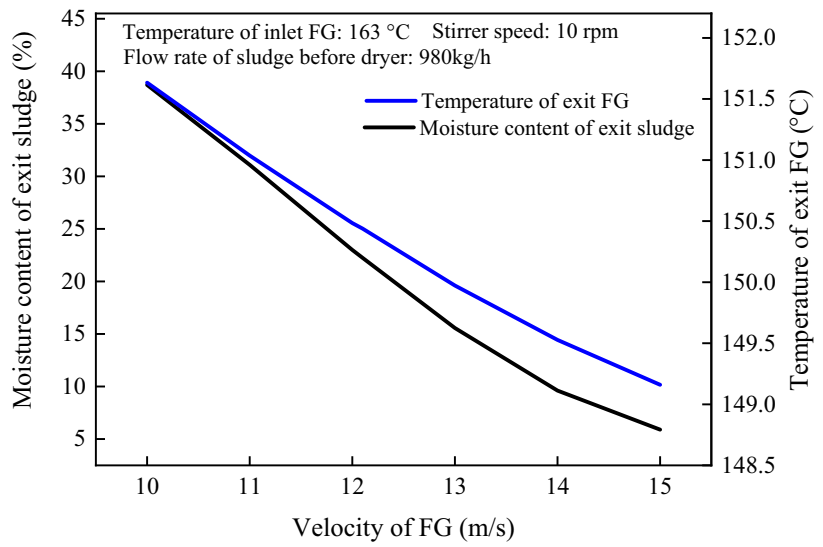

Fig. 7 Variation of moisture content of exit sludge and temperature of exit FG with the velocity of FG 


\section{Influence of sludge drying}

To understand the influence of integrating sludge drying on the performance of the wastewater treatment and the CHP plant, the following key performance indicators (KPIs) are considered: the amount of water rejected from FGQ to the boiler, which can affect the wastewater treatment, the combustion and the energy efficiency of CHP, the external water use, the electricity and heat generation and the overall energy efficiency of CHP plant.

The performances of CHP without and with sludge drying are compared in Table 3 . The feeding rate of sludge was $980 \mathrm{~kg} / \mathrm{h}$, and the moisture content after drying is $40 \%$. In general, the influence of the integration of sludge drying is limited, which may be due to the low feeding rate of sludge. In order to understand the impacts better, sensitivity study is carried out regarding the feeding rate of sludge.

\subsection{Influence on FGQ}

\subsubsection{Influence of feeding rate of sludge on $F G Q$}

Figure 8 presents the impacts of sludge co-incineration and drying on FGQ. When the feeding rate of sludge increases, since more heat is needed to dry sludge, the FG temperature entering FGQ drops, resulting in a decrease of water evaporation. The water evaporation in FGQ decreases from 9560 to $7050 \mathrm{~kg} / \mathrm{h}$ with the increase in feeding rate of sludge from 980 to $8460 \mathrm{~kg} / \mathrm{h}$. After drying, sludge is coincinerated. Due to lower heating values compared to biomass, using sludge can increase the mass flow of fuel, and consequently increase the flow rate of FG. With the increase in the flow rate of FG, more pollutant can come to water in FGQ. Since it has been assumed that the pollutant concentrations remained at a certain level in FGQ, in order to mitigate the accumulation of pollutants in the water in FGQ, more water rich in pollutant needs to be discharged, leading to that the flow rate of reject water increased from 721 to $728 \mathrm{~kg} / \mathrm{h}$. When FGC is not running, as there is no wastewater to be treated, increasing the flow rate of sludge is favorite to reduce the demand of external water.

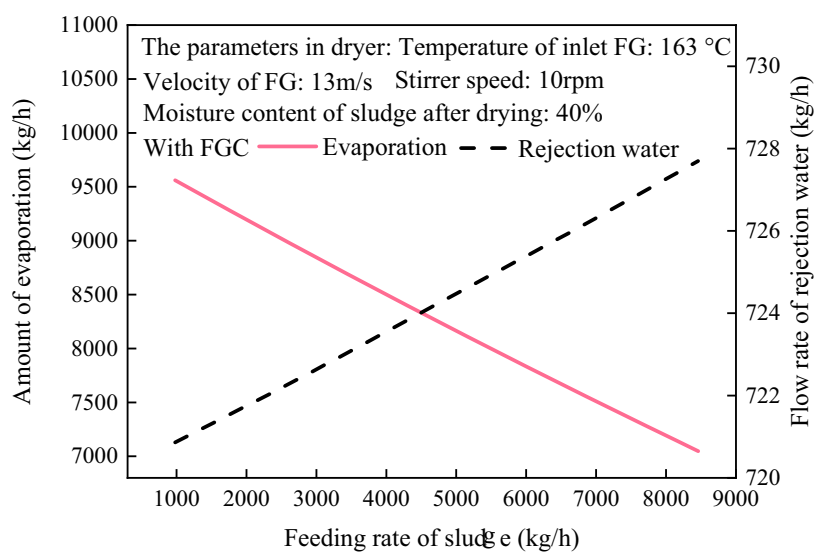

Fig. 8 Impacts of the sludge co-incineration with different feeding rate on FGQ

\subsubsection{Influence of moisture content of sludge after drying on $F G Q$}

Figure 9 shows the impacts of exit sludge in dryer at different moisture content on FGQ. The moisture content of sludge after drying being co-incinerated is varied from 30 to $50 \%$, and to better clear the impacts of moisture content, the amount of feeding sludge in dryer is the maximum value that can be dried by FG at respective moisture content. The sludge feeding rate increases with the increase in moisture content of exit sludge, which can be obtained by the iteration. With the increase in moisture content of sludge after drying, the water evaporation in FGQ decreases clearly, from 7530 to $6230 \mathrm{~kg} / \mathrm{h}$. This is mainly owing to that the high moisture content of sludge after drying can result in a high moisture content in FG. As FGQ is a process of humidification, when the inlet FG contains more water, less water can be evaporated. And similar to the influence of feeding rate of sludge, a less water evaporation leads to an increase in rejection water in order to keep the pollutant level in FGQ.

\subsection{Influence on CHP}

The integration of sludge drying into the CHP plant system can change the mass flow of fuel and the properties of FG, which can affect the heat recovery from FG.
Table 3 Performance comparison for CHP with and without sludge drying

\begin{tabular}{lll}
\hline & With sludge drying & Without sludge drying \\
\hline Electricity and heat generation (MW) & 146 & 146 \\
Heat recovery (MW) & 27.4 & 28 \\
Energy efficiency (\%) & $85.9 \%$ & $87.4 \%$ \\
Reject water $(\mathrm{kg} / \mathrm{h})$ & 721 & 717 \\
Condensate water $(\mathrm{ton} / \mathrm{h})$ & 42.8 & 43.2 \\
Evaporation water in $\mathrm{FGQ}(\mathrm{kg} / \mathrm{h})$ & 9560 & 9756
\end{tabular}




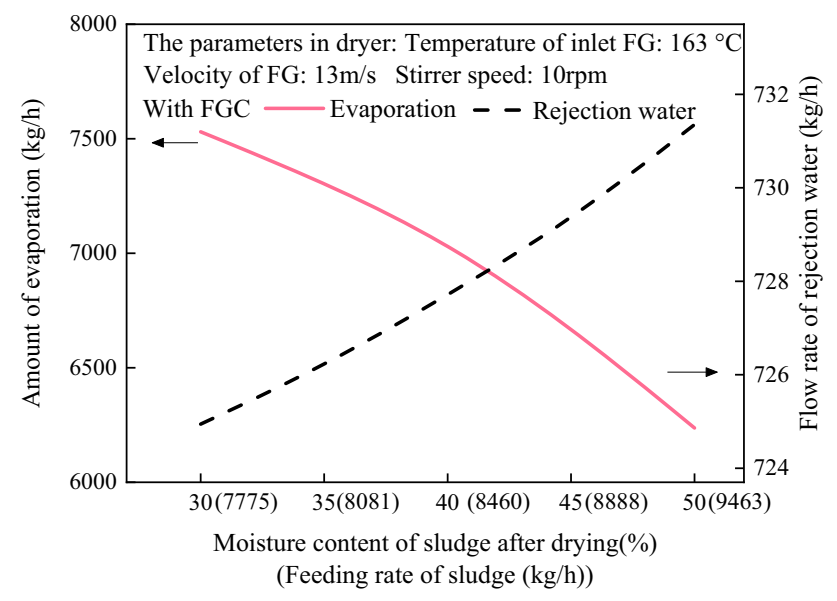

Fig. 9 Impacts of the sludge co-incineration with different moisture content on FGQ

\subsubsection{Influence of feeding rate of sludge on CHP}

Figure 10a shows the impacts of the flow rate of sludge on the heat recovery and system energy efficiency when FGC is running. It is assumed that sludge is dried to a water content of $40 \%$. When using sludge to replace biomass after drying, as the share of sludge is very low, accounting for only $8.7 \%$ of the total fuel, which is about $8460 \mathrm{~kg} / \mathrm{h}$, the impacts on operation of the boiler and the steam Rankine cycle are limited. And due to the assumption that the combustion temperature and the steam flow rate are constant, there is no change in the power generation. However, since some heat is used for sludge drying, less heat is recovered from FGC, resulting in a reduced heat recovery. When the flow rate of sludge is increased from 980 to $8460 \mathrm{~kg} / \mathrm{h}$, the heat recovery is reduced from 27.4 to 26.76 MW. Consequently, the overall energy efficiency (including both electricity and heat) decreases from 85.9 to $83.1 \%$.

When FGC was not running in summer, the impacts are shown in Fig. 10b. The generation of both heat and power is not influenced; whereas, the overall energy efficiency decreases from 72.3 to $70.2 \%$. It is mainly owing to the coincineration of sludge, which has lower heating values, resulting in a larger heat loss in FG.

\subsubsection{Influence of moisture content of sludge after drying on $\mathrm{CHP}$}

Figure 11a shows the impacts of the moisture content of sludge after drying on the heat recovery and overall energy efficiency when FGC is running. The moisture content is varied from 30 to $50 \%$. When less water is removed from sludge, less heat is needed. Therefore more heat can be recovered in FGC. Even though, the overall energy

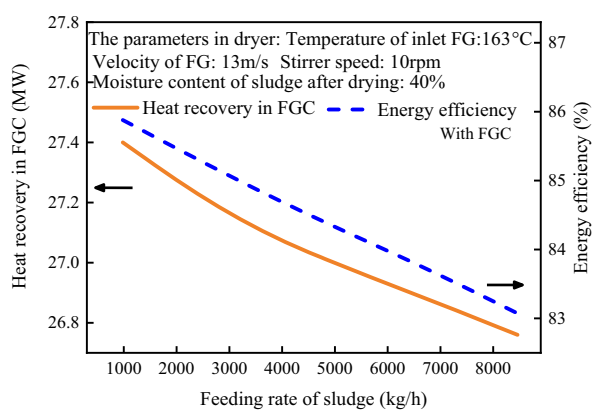

(a) Impacts of feeding rate of sludge on heat recovery and energy efficiency (with FGC).

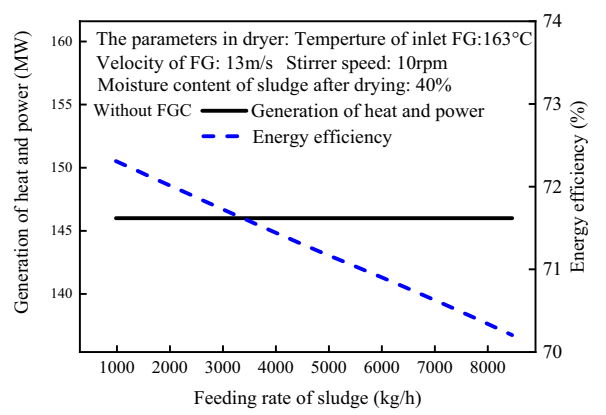

(b) Impacts of feeding rate of sludge on generation of heat and power and energy efficiency (without FGC).

Fig. 10 Impacts of feeding rate of sludge on CHP

efficiency is decreased from 84.2 to $81.3 \%$ due to the low heat values of dried sludge.

When FGC was not running, as shown in Fig. 11b, it is same as the impact when the flow rate of sludge increased.

\subsubsection{Influence of sludge drying on biomass/waste fuel savings}

After drying, sludge can replace some biomass as fuel. The saved biomass is illustrated in Fig. 12. Co-incineration of sludge with $40 \%$ moisture content in boiler can save biomass/waste flow. However, savings in biomass fuel $(\mathrm{kg} / \mathrm{h})$ is less than sludge input $(\mathrm{kg} / \mathrm{h})$ because the heating value of sludge is lower than biomass. In general, biomass savings $(\mathrm{kg} / \mathrm{h})$ is equivalent to around $\sim 45 \%$ of sludge flow $(\mathrm{kg} / \mathrm{h})$ that is co-incinerated in boiler.

The influence of the moisture content after drying on the saving of biomass fuel is also investigated. The sludge is dried from its initial $80 \%$ moisture content to $30-50 \%$ before it is co-incinerated with biomass in boiler. Figure 13 shows how the saving of biomass/waste varies with moisture contents after drying. The moisture content of sludge after drying determines the maximum amount of sludge that can be dried. For example, if the moisture content after drying is $30 \%$, only $7775 \mathrm{~kg} / \mathrm{h}$ of sludge can be dried. When it is used as fuel for combustion, it can save around $2228 \mathrm{~kg} / \mathrm{h}$ of biomass. When the moisture content after drying is increased, with the same amount of heat from FG, 


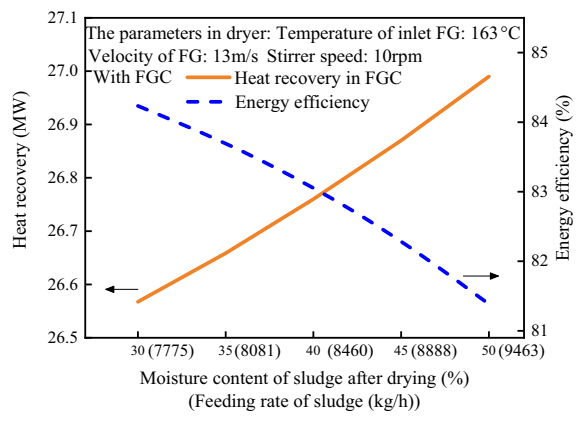

(a) Impacts of moisture content of exit sludge on generation of heat and power and energy efficiency (with FGC).

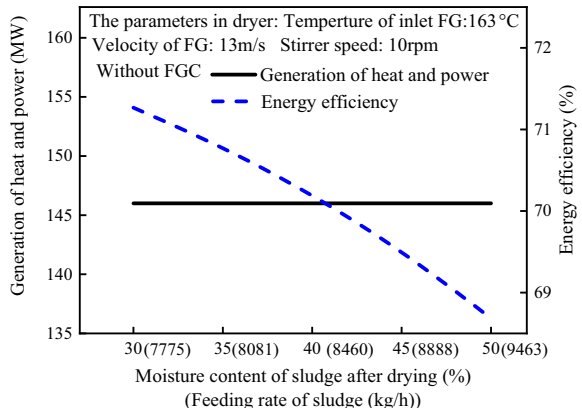

(b) Impacts of moisture content of feed sludge on the generation of heat and power and energy efficiency (without FGC).

Fig. 11 Impacts of moisture content of exit sludge on CHP

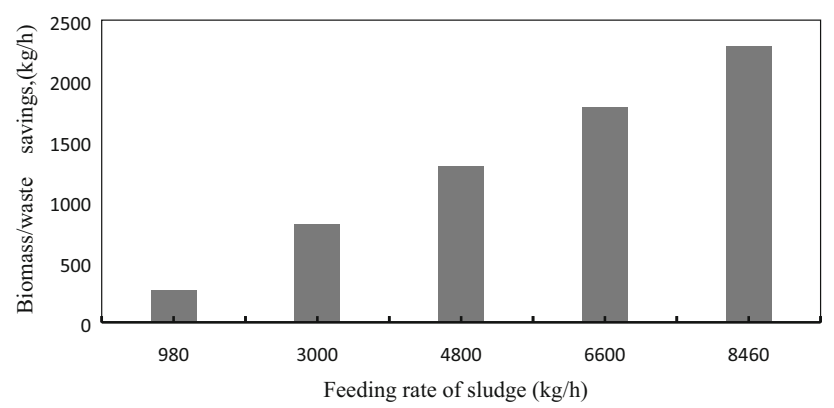

Fig. 12 Impacts of feeding rate of sludge on biomass/waste fuel savings

more sludge can be dried and more biomass can be replaced. However, the further increase in sludge moisture can decrease the biomass saving. The reason is the high moisture content in the dried sludge has a negative impact on the combustion temperature. In order to maintain the temperature in the boiler, more biomass is needed. The maximum saving appeares at the moisture content of $40 \%$.

\section{Conclusions}

Drying is an important step to handle sludge, which consumes a large amount of heat. Using waste heat from flue gas (FG) is a promising solution. This work studies the

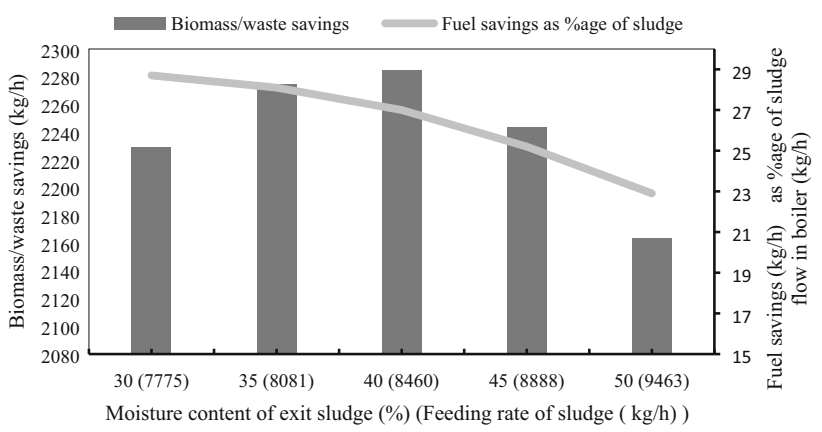

Fig. 13 Impacts of moisture content of exit sludge on biomass/waste fuel savings

potential impacts of integrating sludge drying in a biomass fueled CHP plant on the performance of downstream processes, such as flue gas quench (FGQ) and flue gas condenser (FGC). Based on the simulation results, the following conclusions can be drawn:

1. The water evaporation in FGQ is obviously affected by the feeding rate of sludge and the moisture content of sludge after drying. With increase in feeding rate and moisture content of sludge after drying, the amount of water evaporation decreases. When FGC is not in operation, they are favorite to reduce the external water use.

2. Sludge drying can also clearly affect the energy performance of CHP. The rise of feeding rate of sludge while the drop of moisture content of sludge after drying can decrease the heat recovery from FG.

3. After sludge is dried, it can be used as fuel to replace biomass. The moisture content and flow rate of sludge can affect the amount of biomass saving. For the studied CHP plant, drying sludge to the moisture content of $40 \%$ shows the maximum amount of biomass saving.

Acknowledgments The Knowledge Foundation in Sweden (KKS) is acknowledged for their financial support for the KKS-Hög Project: WASTEMAN (No. 20170185).

Authors' contributions J.W.: developed the model of sludge drying and wrote the paper; C.A.S.: developed the model of CHP and wrote the paper; B.W.: developed the model of sludge drying; H.L.: attracted the funding, conceived and designed the analysis and wrote the paper; E.T.: provided critical feedback and helped shape the analysis and manuscript

Funding Open access funding provided by Mälardalen University.

\section{Compliance with ethical standards}

Conflict of interest The authors declare that they have no conflict of interest. 
Open Access This article is licensed under a Creative Commons Attribution 4.0 International License, which permits use, sharing, adaptation, distribution and reproduction in any medium or format, as long as you give appropriate credit to the original author(s) and the source, provide a link to the Creative Commons licence, and indicate if changes were made. The images or other third party material in this article are included in the article's Creative Commons licence, unless indicated otherwise in a credit line to the material. If material is not included in the article's Creative Commons licence and your intended use is not permitted by statutory regulation or exceeds the permitted use, you will need to obtain permission directly from the copyright holder. To view a copy of this licence, visit http://creativecommons. org/licenses/by/4.0/.

\section{References}

Akdağ AS, Atak O, Atimtay AT, Sanin FD (2018) Co-combustion of sewage sludge from different treatment processes and a lignite coal in a laboratory scale combustor. Energy 158:417-426. https://doi.org/10.1016/j.energy.2018.06.040

Ameri B, Hanini S, Boumahdi M (2020) Influence of drying methods on the thermodynamic parameters, effective moisture diffusion and drying rate of wastewater sewage sludge. Renew Energy 147:1107-1119. https://doi.org/10.1016/j.renene.2019.09.072

Arlabosse P, Chitu T (2007) Identification of the limiting mechanism in contact drying of agitated sewage sludge. Dry Technol 25:557-567. https://doi.org/10.1080/07373930701226955

Arlabosse P, Ferrasse JH, Lecomte D, Crine M, Dumont Y, Léonard A (2011) Efficient sludge thermal processing: from drying to thermal valorization. Mod Dry Technol Energy Sav 4:295-329. https://doi.org/10.1002/9783527631681.ch8

Ayol A, Yurdakos OT, Gurgen A (2019) Investigation of municipal sludge gasification potential: gasification characteristics of dried sludge in a pilot-scale downdraft fixed bed gasifier. Int J Hydrog Energy 44(32):17397-17410. https://doi.org/10.1016/j.ijhydene. 2019.01.014

Bennamoun L, Arlabosse P, Leonard A (2013) Review on fundamental aspect of application of drying process to wastewater sludge. Renew Sust Energy Rev. https://doi.org/10.1016/j.rser. 2013.07.043

Bianchini A, Bonfiglioli L, Pellegrini M, Saccani C (2015) Sewage sludge drying process integration with a waste-to-energy power plant. Waste Manag 42(aug):159-165. https://doi.org/10.1016/j. wasman.2015.04.020

Charlou C, Milhe M, Sauceau M, Arlabosse P (2015) A new methodology for measurement of sludge residence time distribution in a paddle dryer using X-ray fluorescence analysis. Water Res. https://doi.org/10.1016/j.watres.2014.11.005

Chen S, Wang F, Milhé M, Arlabosse P, Liang F, Chi Y, Nzihou A, Yan J (2016) Experimental and theoretical research on agitated contact drying of sewage sludge in a continuous paddle dryer. Dry Technol 34(16):1979-1990. https://doi.org/10.1080/ 07373937.2016.1147457

Chen SQ, Wang F, Chi Y, Yan JH, Cen KF (2017) Analysis on mass and energy balance of sludge drying and incineration system. Chin J Environ Eng 11(1):515-521. https://doi.org/10.12030/j. cjee. 201508185

Chin S, Jurng J, Lee JH, Hur JH (2008) Oxygen-enriched air for coincineration of organic sludges with municipal solid waste: a pilot plant experiment. Waste Manag 28(12):2684-2689. https:// doi.org/10.1016/j.wasman.2008.01.004

Dai Z, Su M, Ma X, Wang G, Li D, Liu C, Weng H (2018) Direct thermal drying of sludge using flue gas and its environmental benefits. Dry Technol 36(8):1006-1016. https://doi.org/10.1080/ 07373937.2017 .1368541

Deng WY, Yan JH, Li XD, Wang F, Lu SY, Chi Y, Cen KF (2009) Measurement and simulation of the contact drying of sewage sludge in a Nara-type paddle dryer. Chem Eng Sci 64(24):5117-5124. https://doi.org/10.1016/j.ces.2009.08.015

Deng W, Su Y, Yu W (2013) Theoretical calculation of heat transfer coefficient when sludge drying in a nara-type paddle dryer using different heat carriers. Proc Environ Sci 18:709-715. https://doi. org/10.1016/j.proenv.2013.04.096

Emad AH, Nils G (2017) Sustainable flue-gas quench: for waste incineration plants within a water-energy-environment nexus perspective. Dissertation, Mälardalen University

Farid MAA, Roslan AM, Hassan MA, Ujang FA, Mohamad Z, Hasan MY, Yoshihito S (2019) Convective sludge drying by rotary drum dryer using waste steam for palm oil mill effluent treatment. J Clean Prod 240:117986. https://doi.org/10.1016/j. jclepro.2019.117986

Ferrasse JH, Arlabosse P, Lecomte D (2002) Heat, momentum, and mass transfer measurements in indirect agitated sludge dryer. Dry Technol 20(4-5):749-769. https://doi.org/10.1081/DRT120003755

Fraikin L, Salmon T, Herbreteau B, Levasseur JP, Nicol F, Crine M, Léonard A (2011) Impact of storage duration on the gaseous emissions during convective drying of urban residual sludges. Chem Eng Technol 34(7):1172-1176. https://doi.org/10.1002/ ceat.201100071

Galanopoulos C (2015) Impact analysis for major emissions from combustion of contaminated wooden fuels. Dissertation, KTH Royal Institute of Technology

Kim JH, Oh JI, Lee J, Kwon EE (2019) Valorization of sewage sludge via a pyrolytic platform using carbon dioxide as a reactive gas medium. Energy 179:163-172. https://doi.org/10.1016/j.energy. 2019.05.020

Kor-Bicakci G, Ubay-Cokgor E, Eskicioglu C (2019) Effect of dewatered sludge microwave pretreatment temperature and duration on net energy generation and biosolids quality from anaerobic digestion. Energy 168:782-795. https://doi.org/10. 1016/j.energy.2018.11.103

Kuan YH, Wu FH, Chen GB, Lin HT, Lin TH (2020) Study of the combustion characteristics of sewage sludge pyrolysis oil, heavy fuel oil, and their blends. Energy. https://doi.org/10.1016/j. energy.2020.117559

Kudra T (2003) Sticky region in drying - definition and identification. Dry Technol 21(8):1457-1469. https://doi.org/10.1081/DRT120024678

Lee U, Balu E, Chung JN (2013) An experimental evaluation of an integrated biomass gasification and power generation system for distributed power applications. Appl Energy 101:699-708. https://doi.org/10.1016/j.apenergy.2012.07.036

Léonard A, Meneses E, Le TE, Salmon T, Marchot P, Toye D, Crine $M$ (2008) Influence of back mixing on the convective drying of residual sludges in a fixed bed. Water Res 42(10-11):2671-2677. https://doi.org/10.1016/j.watres.2008.01. 020

Li H, Wang B, Yan J, Salman CA, Thorin E, Schwede S (2019) Performance of flue gas quench and its influence on biomass fueled CHP. Energy 180:934-945. https://doi.org/10.1016/j. energy.2019.05.078

Ma XW, Weng HX, Su MH, Pan L (2012) Drying sewage sludge using flue gas from power plants in China. Environ Earth Sci 65(6):1841-1846. https://doi.org/10.1007/s12665-011-1166-x

Mahmoud A, Olivier J, Vaxelaire J, Hoadley AF (2010) Electrical field: a historical review of its application and contributions in wastewater sludge dewatering. Water Res 44(8):2381-2407. https://doi.org/10.1016/j.watres.2010.01.033 
Milhé M, Charlou C, Sauceau M, Arlabosse P (2015) Modeling of sewage sludge flow in a continuous paddle dryer. Dry Technol 33(9):1061-1067. https://doi.org/10.1080/07373937.2014. 982252

Milhé M, Sauceau M, Arlabosse P (2016) Modeling of a continuous sewage sludge paddle dryer by coupling Markov chains with penetration theory. Appl Math Model 40(19-20):8201-8216. https://doi.org/10.1016/j.apm.2016.04.006

Murakami T, Suzuki Y, Nagasawa H, Yamamoto T, Koseki T, Hirose H, Okamoto S (2009) Combustion characteristics of sewage sludge in an incineration plant for energy recovery. Fuel Process Technol 90(6):778-783. https://doi.org/10.1016/j.fuproc.2009. 03.003

Salman CA, Naqvi M, Thorin E, Yan J (2017) Impact of retrofitting existing combined heat and power plant with polygeneration of biomethane: a comparative techno-economic analysis of integrating different gasifiers. Energy Convers Manag 152:250-265. https://doi.org/10.1016/j.enconman.2017.09.022

Salman CA, Schwede S, Thorin E, Li H, Yan J (2019) Identification of thermochemical pathways for the energy and nutrient recovery from digested sludge in wastewater treatment plants. Energy Proc 158:1317-1322. https://doi.org/10.1016/j.egypro. 2019.01.325

Schnell M, Horst T, Quicker P (2020) Thermal treatment of sewage sludge in Germany: a review. J Environ Manag 263:110367. https://doi.org/10.1016/j.jenvman.2020.110367

Stockholm Water and Waste (2019) "Quality and control". http:// www.stockholmvatten.se/en/water-and-wastewater/drinkingwater/quality-and-control/. Accessed 12 Jan 2019
Tańczuk M, Kostowski W, Karaś M (2016) Applying waste heat recovery system in a sewage sludge dryer-a technical and economic optimization. Energy Convers Manag 125:121-132. https://doi.org/10.1016/j.enconman.2016.02.064

The council of the European Union (1999) "Council Directive 1999/31/EC of 26 April 1999 on the landfill of waste". https:// eur-lex.europa.eu/legal-content/EN/TXT/HTML/?uri=CELEX: 31999L0031\&qid=1587699810546\&from=EN. Accessed 12 April 2020

Tsotsas E, Schlünder EU (1986) Contact drying of mechanically agitated particulate material in the presence of inert gas. Chem Eng Process 20(5):277-285. https://doi.org/10.1016/02552701(86)80021-6

Wang R, Wang C, Zhao Z, Jia J, Jin Q (2019a) Energy recovery from high-ash municipal sewage sludge by hydrothermal carbonization: fuel characteristics of biosolid products. Energy 186:115848. https://doi.org/10.1016/j.energy.2019.07.178

Wang B, Wang J, Li H, Thorin E, Schwede S (2019b) Feasibility analysis of drying sludge using flue gas waste heat. In: DEStech Transactions on Environment, Energy and Earth Sciences (ICEEE). https://doi.org/10.12783/dteees/iceee2019/31826

Xu J, Liao Y, Yu Z, Cai Z, Ma X, Dai M, Fang S (2018) Cocombustion of paper sludge in a $750 \mathrm{t} / \mathrm{d}$ waste incinerator and effect of sludge moisture content: a simulation study. Fuel 217:617-625. https://doi.org/10.1016/j.fuel.2017.12.118

Zheng A, Li L, Tippayawong N, Huang Z, Zhao K, Wei G, Zhao Z, Li $\mathrm{H}$ (2020) Reducing emission of NOx and SOx precursors while enhancing char production from pyrolysis of sewage sludge by torrefaction pretreatment. Energy 192(2020):116620. https://doi. org/10.1016/j.energy.2019.116620 